\title{
Assessment of dental arch relationships in 5-year-old children with unilateral cleft lip and palate after neonatal cleft lip repair
}

\author{
Margarita Rousi \\ Fakultni nemocnice u sv Anny v Brne \\ Alena Brysova \\ Fakultni nemocnice u sv Anny v Brne \\ Jitka Vokurkova \\ Fakultni nemocnice Brno Detska nemocnice \\ Olga Koskova ( $\sim$ koskova.olga@gmail.com) \\ University Hospital Brno \\ Lydie Izakovicova Holla \\ Fakultni nemocnice u sv Anny v Brne
}

\section{Research article}

Keywords: unilateral cleft lip and palate, neonatal cleft lip repair, the 5 Year Olds' index

Posted Date: October 7th, 2020

DOI: https://doi.org/10.21203/rs.3.rs-66819/v1

License: (c) (i) This work is licensed under a Creative Commons Attribution 4.0 International License. Read Full License 


\section{Abstract \\ Background}

Non-syndromic cleft lip and palate (CLP) is one of the most common craniofacial malformations. The purpose of this study was to assess the dental arch relationships in 5-year-old children with non-syndromic unilateral cleft lip and palate (UCLP) and to compare the results with the data published by other cleft centers.

\section{Methods}

The models of forty-six patients with unilateral cleft lip and palate taken at the age of five were scored. Neonatal cleft lip repair and one-stage palatal closure at the age from 6 to 13 months were performed in all patients by the same surgeon according to the same protocol. The outcomes of the dental arch relationships were assessed and categorized by three orthodontists experienced in cleft care; for scoring the 5 Year Olds' index was used.

\section{Results}

The mean score of the 5 Year Olds' index was 2.42. Of all the patients, $57 \%$ belonged to groups 1 and 2 (good result), $24 \%$ to group 3 (fair result), and 19\% to groups 4 and 5 (poor result). These results were compared with the data published by other cleft centers. The outcomes of our method were comparable to the results achieved by other cleft centers which followed different surgical protocols.

\section{Conclusions}

The results of our study showed that neonatal cleft lip repair and one-stage palatal closure lead to satisfactory maxillary growth and interdental relationships.

\section{Background}

Orofacial clefts are one of the most common craniofacial birth defects. They can occur as part of Mendelian syndromes or, in the majority of cases, as isolated nonsyndromic events [1]. This complex disorder is caused by the interaction of multiple genetic and environmental risk factors. The defects include unilateral or bilateral cleft lip, isolated cleft palate or cleft lip and palate. The main treatment goals for children with cleft lip and palate are to harmonize the growth of the maxilla, achieve good interdental relationships, enable correct speech and, last but not least, an ideal aesthetic result. To reach this, a multidisciplinary team of specialists should take care of these children from the day of their birth to their adulthood.

The first part of the treatment is, most commonly, surgery of the lip followed by surgery of the palate. This part of the treatment is essential for the future outcome of maxillary growth. The timing of the operation differs according to protocols used in the individual cleft center. According to the literature, the closure of the lip can be performed neonatally [2, 3], at three months of age [4] or even later [5]. The guidelines of the American Cleft Palate Craniofacial Association suggest that the operation of the lip should be performed as early as the surgical repair is considered safe for the infant, however, precise guidelines for the timing of the lip defect operation do not yet exist. The presence of an experienced pediatric anesthesiologist during the operation is highly recommended/required (American Cleft Palate-Craniofacial Association, 2018).

The neonatal surgical approach has a series of benefits not only for the newborns but also for their families [6, 7]. First, the neonatal operation of the lip leads to the improved appearance of the surgical scars and better wound healing due to the elevated levels of hyaluronic acid in the neonatal period [8]. Moreover, after closure of the lip defect the feeding of the newborn is easier and, most importantly, a stronger maternal/infant relationship can be built [9].

Several methods for the evaluation of dental occlusion in patients with unilateral cleft lip and palate for the assessment of the primary surgical outcome have been published [10]. In 1987, Mars et al. introduced the Goslon (Great Ormond Street, London and Oslo) Yardstick Index for the evaluation of interdental relationships at the age of ten years [11], In 1997, Atack introduced the 5 Year Olds' index which allows an earlier assessment of dental occlusion in children with CLP [12].

The aims of this study were to evaluate the dental arch relationships and the effect of the surgery carried out according to the protocol of the Department of Pediatric Plastic Surgery, University Hospital Brno for the growth of the maxilla in five-year-old children, who underwent cleft lip 
repair at a neonatal age and one-stage palatal closure at the age of 6-13 months, and to compare our results with the data published by other cleft centers worldwide.

\section{Methods}

The models taken from 46 subjects with non-syndromic unilateral cleft lip and palate (UCLP), born in the Czech Republic between 2009 and 2013, who underwent the operation at the Department of Pediatric Plastic Surgery, at the University Hospital Brno, were assessed in this study. The surgical protocol followed was the neonatal operation of the lip (2-28 days of life) and one-stage palatal closure performed between 6 and 13 months of age. The surgical part of the treatment was carried out by one experienced plastic surgeon (Vokurkova, MD).

The inclusion criteria were: children born with unilateral cleft lip and palate, having dental records at five years of age, and who had no active orthodontic treatment or secondary alveolar bone grafting till that time point. All procedures performed in studies involving human participants were in accordance with the ethical standards of the institutional and/or national research committee and with the $1964 \mathrm{Helsinki}$ declaration and its later amendments or comparable ethical standards (1G/2017). The study was supported by the project MUNI/A/1428/2019. Informed consent was obtained from all parents of the children included in the study. Specific informed consent to publish the information/images was signed. The patients with other types of clefts, and those with associated syndromes or who had been previously submitted to any active orthodontic or orthopedic procedure were excluded from the study.

The 5 Year Olds' index is one of the most commonly used tools to assess surgical outcome in UCLP at the age of five years (Table 1). The index was adapted for deciduous dentition by Atack [12] who based it on the Goslon Yardstick index used for late mixed dentition in ten-year-old patients [11]. This 5-point scoring system allows to assess the dental arch relationships in the sagittal, vertical and transversal dimensions and predict a long-term outcome in each patient from a score of 1 (excellent) to 5 (very poor):

- Score 1: Positive overjet with average inclined or retroclined incisors with no crossbite or open bite and a good maxillary shape and palatal vault anatomy.

Long-term outcome: excellent

- Score 2: Positive overjet with average inclined or retroclined incisors, unilateral crossbite or crossbite tendency, with or without open bite tendency around the cleft site.

Long-term outcome: good

- Score 3: Edge to edge bite with average inclined or proclined incisors or reverse overjet with retroclined incisors. Unilateral crossbite with or without open bite tendency at the cleft site.

Long-term outcome: fair

- Score 4: Reverse overjet with average inclined or proclined incisors. Unilateral crossbite, with or without bilateral crossbite tendency, with or without open bite tendency around the cleft site.

Long-term outcome: poor

- Score 5: Reverse overjet with proclined incisors, bilateral crossbite and poor maxillary arch from palatal vault anatomy.

Long-term outcome: very poor

Table 1. The 5 Year Olds' index scoring system. 


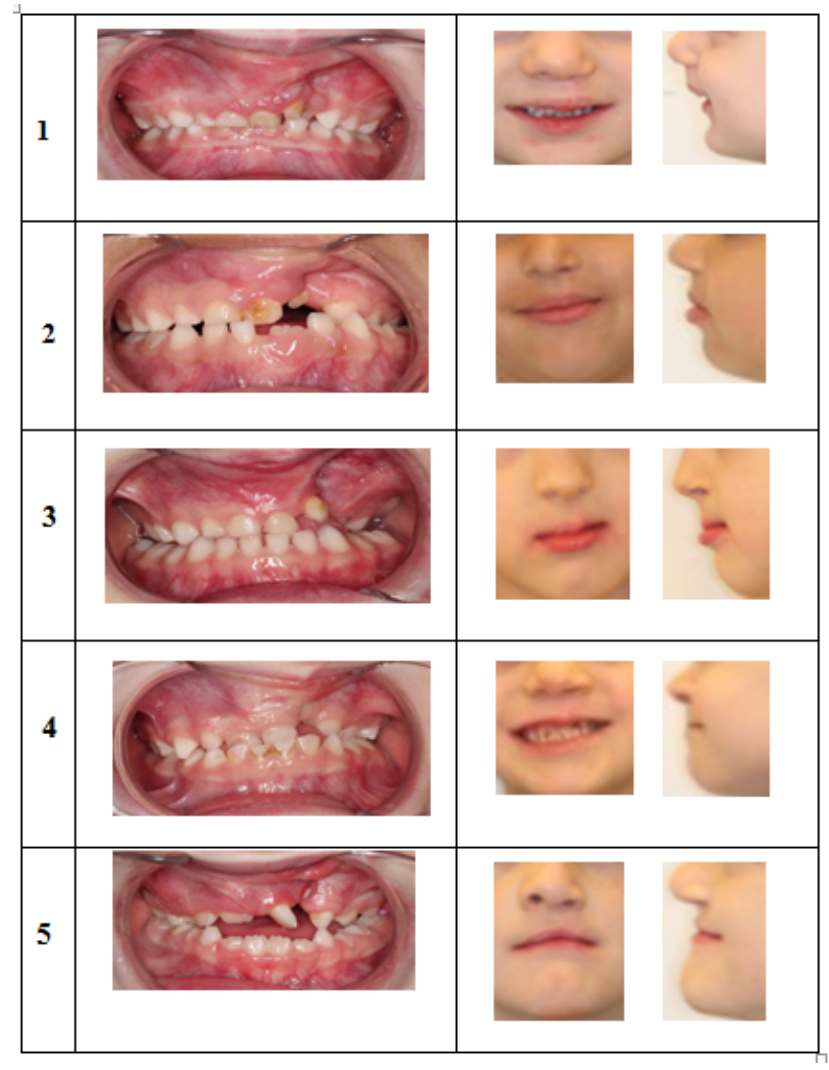

Dental models in printed and scanned forms imported into a digital imaging software program (OrthoCad) were used for the assessment (Figure 1). The dental records and impressions of both jaws were obtained at the Orthodontic Department, Clinic of Dentistry at St. Anne's Faculty Hospital, Brno. Each model was randomly assigned a code to anonymize the patients' records. The evaluation was performed by three experienced orthodontists at two different time points. Prior to this, each examiner was familiarized with the use of the 5 Year Olds' index so that any systematic bias could be prevented.

The results of this study were compared with the outcomes published by other cleft centers worldwide. The search of the data was made through the Medline database and by applying a custom date range from 1997 till 2019. By using the key words "the 5 Year Olds' index", "cleft lip and palate", and "dental arch relationships", 95 articles were identified and thirteen studies fulfilled the required criteria: the evaluation of dental arch relationships in five-year-old children with non-syndromic unilateral cleft lip and palate.

\section{Statistical analysis}

The obtained data was described as the absolute and relative frequencies and expressed using the mean, standard deviation (SD) and median. The intrarater reliability was assessed by Cohen's kappa. The interrater reliability of three examiners was measured using Fleiss' kappa. The agreement between two examiners was assessed using Cohen's kappa with 95\% confidence intervals (95\% Cl). Cohen suggested the Kappa result to be interpreted as follows: values $\leq 0$ as indicating no agreement and $0.01-0.20$ as none to slight, $0.21-0.40$ as fair, $0.41-0.60$ as moderate, $0.61-0.80$ as substantial, and $0.81-1.00$ as almost perfect agreement. (Mary L. McHugh Interrater reliability: The kappa statistics, Biochem Med 2012). The agreement between the determined measurements was also expressed in terms of relative frequencies with $95 \% \mathrm{Cl}$. IBM SPSS Statistics for Windows, Version 23.0 statistical software was used for statistical processing. Armonk, NY: IBM Corp.

\section{Results}

The models of totally 46 patients were assessed; the subjects' mean age at the time of taking the dental impressions was 5.3 years old. Among the selected subjects, 35 patients were boys (72.9\%); the unilateral cleft lip and palate affected the left side in $70 \%$ of the children included in the study. The mean age at the time of the cleft lip surgery was 6.7 days and the mean age of the palatal surgery was 7.5 months.

The evaluation of the 5 Year Olds' index was performed by three experienced orthodontists at two different time points. The intrarater agreement between the first and second measurement achieved by each examiner was from 0.614 (third examiner) to 0.648 (second examiner), which means substantial agreement. The examiner 2 had the highest agreement rate, the first and the second measurements were in agreement in $73.9 \%$ patients. Examiners 2 and 3 achieved agreement in $71.7 \%$ of cases between the first and second measurements (Table 2 ). 
The total interrater agreement achieved by all the three examiners was more than substantial, as represented by the Fleiss' kappa values of 0.836 and 0.873 in the first and second measurements, respectively (data not shown).

Of all the patients, $57 \%$ were rated as belonging to groups 1 and 2 with an excellent and good prognosis, $24 \%$ to group 3 with a fair prognosis requiring more complex orthodontic management, and $19 \%$ to groups 4 and 5 with a predicted need of orthognathic surgery in the future (Figure 2). The mean score of the 5 Year Olds' index was 2.42 ( \pm 1.04 SD) and the median value was 2.0.

The results of our study were compared with the outcomes of other cleft centers worldwide with different surgical protocols (Table 3 ). The treatment protocol, neonatal cleft lip repair and one-stage palatal closure, which we follow in our cleft center, produced the index score that approximated the results achieved by other cleft centers (Figure 3).

Table 2: Intrarater agreement of score 1 and score 2 determined by three experienced orthodontists:

\begin{tabular}{|c|c|c|c|c|c|c|c|c|c|c|c|c|}
\hline \multirow[t]{3}{*}{ Score } & \multicolumn{4}{|c|}{ Examiner 1} & \multicolumn{4}{|c|}{ Examiner 2} & \multicolumn{4}{|c|}{ Examiner 3} \\
\hline & \multicolumn{2}{|c|}{ Score 1} & \multicolumn{2}{|c|}{ Score 2} & \multicolumn{2}{|c|}{ Score 1} & \multicolumn{2}{|c|}{ Score 2} & \multicolumn{2}{|c|}{ Score 1} & \multicolumn{2}{|c|}{ Score 2} \\
\hline & Count & $\%$ & Count & $\%$ & Count & $\%$ & Count & $\%$ & Count & $\%$ & Count & $\%$ \\
\hline 1 & 10 & 21.7 & 9 & 19.6 & 10 & 21.7 & 9 & 19.6 & 8 & 17.4 & 10 & 21.7 \\
\hline 2 & 14 & 30.4 & 19 & 41.3 & 15 & 32.6 & 18 & 39.1 & 18 & 39.1 & 17 & 37.0 \\
\hline 3 & 14 & 30.4 & 12 & 26.1 & 12 & 26.1 & 11 & 23.9 & 11 & 23.9 & 12 & 26.1 \\
\hline 4 & 7 & 15.2 & 5 & 10.9 & 8 & 17.4 & 7 & 15.2 & 8 & 17.4 & 6 & 13.0 \\
\hline 5 & 1 & 2.2 & 1 & 2.2 & 1 & 2.2 & 1 & 2.2 & 1 & 2.2 & 1 & 2.2 \\
\hline Mean & 2.46 & & 2.35 & & 2.46 & & 2.41 & & 2.48 & & 2.37 & \\
\hline SD & 1.07 & & 0.99 & & 1.09 & & 1.05 & & 1.05 & & 1.04 & \\
\hline Median & 2 & & 2 & & 2 & & 2 & & 2 & & 2 & \\
\hline \multirow[t]{4}{*}{ Statistics } & \multicolumn{4}{|c|}{ Kappa value (SE); 95\% Cl } & \multicolumn{4}{|c|}{ Kappa value (SE); 95\% Cl } & \multicolumn{4}{|c|}{ Kappa value (SE); 95\% Cl } \\
\hline & \multicolumn{4}{|c|}{0.616 (0.090); 0.435-0.797 } & \multicolumn{4}{|c|}{$0.648(0.086) ; 0.475-0.821$} & \multicolumn{4}{|c|}{$0.614(0.090) ; 0.433-0.795$} \\
\hline & \multicolumn{4}{|c|}{ Agreement (95\% Cl) } & \multicolumn{4}{|c|}{ Agreement $(95 \% \mathrm{Cl})$} & \multicolumn{4}{|c|}{ Agreement $(95 \% \mathrm{Cl})$} \\
\hline & \multicolumn{4}{|c|}{$71.7 \%(56.5 \%-84.0 \%)$} & \multicolumn{4}{|c|}{$73.9 \%(58.9 \%-85.7 \%)$} & \multicolumn{4}{|c|}{$71.7 \%(56.5 \%-84.0 \%)$} \\
\hline
\end{tabular}

SE - standard error; $95 \% \mathrm{Cl}-95 \%$ confidence interval

Table 3. The 5 Year Olds' index and comparison to other cleft centers 


\begin{tabular}{|c|c|c|c|c|c|c|c|c|c|c|c|}
\hline $\begin{array}{l}\text { Article } \\
\text { no. }\end{array}$ & $\begin{array}{l}\text { Author, year of } \\
\text { publication }\end{array}$ & Country & $\begin{array}{l}\text { No. of } \\
\text { patients }\end{array}$ & Sample & $\begin{array}{l}\text { Mean age of } \\
\text { patients(yrs) }\end{array}$ & $\begin{array}{l}\text { Score } \\
1 \\
(\%)\end{array}$ & $\begin{array}{l}\text { Score } \\
2 \\
(\%)\end{array}$ & $\begin{array}{l}\text { Score } \\
3 \\
(\%)\end{array}$ & $\begin{array}{l}\text { Score } \\
4 \\
(\%)\end{array}$ & $\begin{array}{l}\text { Score } \\
5 \\
(\%)\end{array}$ & $\begin{array}{l}\text { Mean } \\
\text { score }\end{array}$ \\
\hline 1 & $\begin{array}{l}\text { Williams, } \\
\text { 2001(Williams et al., } \\
\text { 2001) }\end{array}$ & $\begin{array}{l}\text { United } \\
\text { Kingdom }\end{array}$ & 223 & & 5.0 & 5 & 24 & 34 & 18 & 19 & 3.20 \\
\hline 2 & $\begin{array}{l}\text { DiBiase, 2002a } \\
\text { (Dibiase et al., 2002) }\end{array}$ & $\begin{array}{l}\text { Canterbury, } \\
\text { United } \\
\text { Kingdom }\end{array}$ & 44 & & 5.6 & 16 & 41 & 29.50 & 9 & 4.50 & 2.45 \\
\hline 3 & $\begin{array}{l}\text { Bongaarts, 2004a } \\
\text { (Bongaarts et al., } \\
\text { 2004) }\end{array}$ & $\begin{array}{l}\text { The } \\
\text { Netherlands }\end{array}$ & 44 & & 4 & 30 & 45 & 23 & 2 & 0 & 1.97 \\
\hline 4 & $\begin{array}{l}\text { Inese Maulina, 2004a } \\
\text { (Maulina et al., 2004) }\end{array}$ & Latvia & 35 & & 5.7 & 3.10 & 59.40 & 12.50 & 21.80 & 3.10 & 2.60 \\
\hline \multirow[t]{3}{*}{5} & \multirow{3}{*}{$\begin{array}{l}\text { Flinn, 2005㣌 (Flinn et } \\
\text { al., 2005) }\end{array}$} & \multirow[t]{3}{*}{ US+Europe } & \multirow{3}{*}{$\begin{array}{l}118(3 \\
\text { centers })\end{array}$} & A & 5.3 & 33.33 & 38.62 & 21.55 & 3.25 & 3.25 & 2 \\
\hline & & & & B & 5.3 & 30.30 & 33.33 & 29.80 & 6.57 & 0 & 2.10 \\
\hline & & & & C & 5.9 & 21.59 & 37.50 & 24.62 & 10.61 & 5.68 & 2.40 \\
\hline 6 & $\begin{array}{l}\text { Mars, 2006a (Mars et } \\
\text { al., 2006) }\end{array}$ & $\begin{array}{l}\text { United } \\
\text { Kingdom }\end{array}$ & 94 & & 5 & 20 & 52 & 27 & 1 & 0 & 2.10 \\
\hline 7 & $\begin{array}{l}\text { Clark, 2006a (Clark et } \\
\text { al., 2006) }\end{array}$ & $\begin{array}{l}\text { Bristol, } \\
\text { United } \\
\text { Kingdom }\end{array}$ & 30 & & 5.6 & 20 & 37 & 27 & 13 & 3 & 2.43 \\
\hline 8 & $\begin{array}{l}\text { Suzuki, } 2006 \text { (Suzuki } \\
\text { et al., 2006) }\end{array}$ & Japan & 136 & & 5 & 11 & 18.40 & 40.40 & 25 & 5.20 & 2.95 \\
\hline 9 & $\begin{array}{l}\text { Lilja, 2006a (Lilja et } \\
\text { al., 2006) }\end{array}$ & Sweden & 94 & & 5 & 20 & 57 & 26 & 2 & 0 & 2.20 \\
\hline \multirow[t]{2}{*}{10} & \multirow{2}{*}{$\begin{array}{l}\text { Wojtaszekslominska, } \\
2010^{c} \\
\text { (Wojtaszekslominska } \\
\text { et al., 2010) }\end{array}$} & \multirow[t]{2}{*}{ Poland } & \multirow[t]{2}{*}{120} & A & 5.3 & 0 & 18 & 41 & 16 & 25 & 3.50 \\
\hline & & & & B & & 41 & 22 & 25 & 8 & 4 & 2.10 \\
\hline 11 & $\begin{array}{l}\text { Pereira, } 2011^{a} \\
\text { (Pereira et al., 2011) }\end{array}$ & Brazil & 45 & & 4 & 11.10 & 33.30 & 40 & 13.40 & 2.20 & 2.62 \\
\hline 12 & $\begin{array}{l}\text { Southall, } 2012 \\
\text { (Southall et al., 2012) }\end{array}$ & Australia & 66 & & 6.0 & 2 & 18 & 45 & 32 & 3 & 3.17 \\
\hline 13 & $\begin{array}{l}\text { Kajii, } 2013 \text { (Kajii et } \\
\text { al., 2013) }\end{array}$ & Japan & 135 & & 6.9 & 2 & 12 & 64 & 16 & 6 & 3.13 \\
\hline 12 & $\begin{array}{l}\text { Rousi (presented } \\
\text { study) }\end{array}$ & $\begin{array}{l}\text { Czech } \\
\text { Republic }\end{array}$ & 46 & & 5.3 & 57 & & 24 & 19 & & 2.42 \\
\hline
\end{tabular}

a Approximated 5 Year Olds' Index from the graph.

${ }^{\mathrm{b}}$ Centre A and C: no presurgical orthopedics, Centre B: presurgical orthodopedics (passive plate)

${ }^{c}$ Centre A: early gingivoperiosteoplasty, Centre B: no gingivoperiosteoplasty

\section{Discussion}

The outcomes of the cleft surgery are variable and depend on many factors. First of all, the quality of the tissues and the size of the cleft play an important role in how the surgery affects the growth of the maxilla [13]. According to the Eurocleft project, the experience of the surgeon and the facilities of the center where the operation is performed are critical [14].

In 2006, our cleft center in Brno introduced a new surgical protocol: the neonatal operation of the lip and palatal closure performed on patients before reaching one year of age. This surgical approach is also followed in some other countries [15]. The timing of cleft lip repair continues to 
be debated; it varies according to the protocol of the respective centers. Operating on the lip in the neonatal period, due to the high elasticity of the tissues, can work as a natural nasoalveolar molding, helping the two alveolar segments to get closer [16].

The hypothesis that anesthesia in the neonatal period can be more dangerous than when administered at the age of three months may be one of the reasons for some centers not to repair the lip neonatally. However, major advances have been made in neonatal anesthesia and surgery, and more recent studies have indicated that an anesthesia itself does not convey a greater additional risk in the neonatal period than at three months in patients without risk of complications $[17,18]$. Pediatric anesthetic and intensive care support in a specialized center are necessary, and close postoperative monitoring is required $[19,20]$. A recent study evaluating whether the general anesthesia in early infancy affects neurodevelopmental outcomes demonstrated that children who underwent anesthesia in infancy, started school life with no neurodevelopmental risk factors [21].

A study carried out in the Czech Republic by Petráčková et. al who compared the outcomes of two groups of patients with clefts who were operated on neonatally and at a later time showed that the earlier anesthesia did not have a negative impact on the intelligence quotient compared to later anesthesia. Moreover, the earlier cleft lip repair showed a significantly positive impact on the psychosocial development of some children [22].

Regardless of the timing of the surgery, either neonatally or later, surgical treatment of children with unilateral cleft lip and palate will always have an effect on the growth of the maxilla and interdental relationships. As a natural consequence, a surgical intervention leaves scar tissue which restricts the physiological growth of the jaws $[23,24,25]$.

It is desirable to assess the outcome of the primary surgery as early as possible so that the effects of the timing and the surgical techniques can also be evaluated [11]. Besides dental models, several other methods exist for the assessment of dental occlusion such as lateral cephalograms, photographs of study models or even extraoral photographs. The accuracy of extraoral photographs for evaluating the growth of the maxilla has been questioned [26]. However, the use of intraoral photographs for the evaluation of the interdental relationships has been accepted [27].

The 5 Year Olds' index according to Atack is a simple, useful and well-known method for the assessment of maxillary growth and dental occlusion, "clean" from any secondary interventions such as orthodontic or orthopedic treatment or secondary alveolar bone graft surgery. This index allows the assessment of the surgical outcome at the age of five years. The 5 Year Olds' index has been proven as a reliable method for the evaluation of the interdental relationships and comparison of the results between different cleft centers [12]. Moreover, by using this index the need for early treatment in young children can be identified.

In this study, the 5 Year Olds' index demonstrated favorable outcomes of neonatal cleft lip repair and one-stage palatal closure carried out at the age from 6 to 13 months: $57 \%$ of cases will require only simple orthodontic treatment, $24 \%$ will need more complex orthodontic treatment and $19 \%$ will require orthodontic-surgical treatment. It is important to emphasize that prior to the time of the assessment, none of the patients had received any orthodontic or orthopedic treatment.

These favorable results may be due to the fact that all the operations were always performed by one surgeon using the same surgical protocol in all subjects [28]. The surgeries were carried out with the presence of experienced pediatric anaesthesiologists and support of a modern pediatric intensive care unit. The Eurocleft study [29, 30,31] showed that the centers that follow the same protocol of long-term care and have a small number of skilled plastic surgeons demonstrate the best outcomes.

The comparison of the results of our study with those reported by other cleft centers employing different protocols showed that neonatal cleft lip repair and one-stage palatal closure led to satisfactory results in five-year old children, only with a minimal number of patients with poor long-term outcomes. However, the impact of the surgery on the growth of the jaws must also be assessed at older ages, particularly in the peak growth period at the age of 12-14 years [32].

In conclusion, we believe that the neonatal approach performed by skilled plastic surgeons in the centers experienced in neonatal surgery leads to satisfactory results in patients with UCLP without severe risks of complications.

\section{Conclusions}

1. The 5 Year Olds' index is a reliable, simple and quick method for the assessment of interdental relationships.

2. Most of the patients assessed in this study belonged to groups 1 and 2 (excellent and good prognosis).

3. A very low number of patients belonged to groups 4 and 5 (poor prognosis).

4. Our study showed that neonatal cleft lip repair and one-stage palatal closure leads to satisfactory maxillary growth and interdental relationships, our outcomes are comparable with those achieved by other cleft centers employing different protocols. 


\section{Abbreviations}

UCLP

Unilateral cleft lip and palate

CLP

Cleft lip and palate

\section{Declarations}

\section{Ethics approval and consent to participate}

This study was approved by the Committee for Ethics of the St. Anne's Faculty Hospital (1G/2017). The informed consent was obtained from all parents or legal guardians of the children prior to their inclusion in the study in line with the Declaration of Helsinki.

The study was supported and approved by the project MUNI/A/1428/2019.

Signed participate statement was obtained from study participants.

\section{Consent of publication}

Not applicable.

\section{Availability of data and materials}

The datasets analyzed during the current study are available from the corresponding author on reasonable request.

\section{Competing interest}

The authors declare no competing interest.

\section{Funding}

The study was supported by the grant AZV NV17-30439A.

Role of the funder: economical support of the research study (impression materials, salary of the examiners, economical needs of the study)

\section{Authors' contributions}

"Conceptualization, M.R., A.B., J.V., O.K. ; methodology, M.R., A.B. ; formal analysis M.R., A.B., J.V., O.K. , investigation, A.B. ; resources, J.V., O.K. ; data curation, M.R., A.B., J.V., O.K. ; writing-original draft preparation, M.R. ; writing-review and editing, L.I.H., O.K.; supervision, L.I.H., ; funding acquisition, L.I.H.

All authors have read and agreed to the published version of the manuscript.

\section{Acknowledgments}

Not applicable.

\section{References}

1. Leslie EJ, Marazita ML. Genetics of cleft lip and cleft palate. Am J Med Genet Part C Semin Med Genet. 2013;163(4):246-58.

2. Sinko K, Caacbay E, Jagsch R, Turhani D, Baumann A, Mars M. The Goslon Yardstick in Patients with Unilateral Cleft Lip and Palate: Review of a Vienna Sample. The Cleft Palate Craniofac J. 2008;45(1):87-92.

3. Košková O, Vokurková J, Vokurka J, Bryšova A, Šenovský P, Čefelínová J, et al. Treatment outcome after neonatal cleft lip repair in 5-yearold children with unilateral cleft lip and palate. Int J Pediatr Otorhinolaryngol. 2016;87:71-7.

4. Clark SA, Atack NE, Swings P, Hathorn IS, Mercer NSG. Early surgical outcomes in 5-year-old patients with repaired unilateral cleft lip and palate. Cleft Palate Craniofac J. 2007;44(3):235-8.

5. Eichhorn W, Blessmann M, Vorwig O, Gehrke G, Schmelzle R, Heiland M. Influence of lip closure on alveolar cleft width in patients with cleft lip and palate. Head Face Med. 2011;7(1). 
6. Vokurková J, Elstnerová L, Lukášová O, Hufová I. The development of neonatal care and evaluation of the first five years experience in surgery of cleft lip in the neonatal period. Czecho-Slovak Pediatr. 2011;66:356-62.

7. Stock NM, Stoneman K, Cunniffe C, Rumsey N. The Psychosocial Impact of Cleft Lip and/or Palate on Unaffected Siblings. Cleft Palate Craniofac J. 2016;53(6):670-82.

8. Hammoudeh JA, Imahiyerobo TA, Liang F, Fahradyan A, Urbinelli L, Lau J, et al. Early Cleft Lip Repair Revisited: A Safe and Effective Approach Utilizing a Multidisciplinary Protocol. Plast Reconstr surgery -. Glob open. 2017;5(6):e1340.

9. Murray L, Hentges F, Hill J, Karpf J, Mistry B, Kreutz M, et al. The effect of cleft lip and palate, and the timing of lip repair on mother-infant interactions and infant development. J Child Psychol Psychiatry. 2008;49(2):115-23.

10. Gray D, Mossey PA. Evaluation of a modified Huddart/Bodenham scoring system for assessment of maxillary arch constriction in unilateral cleft lip and palate subjects. Eur J Orthod. 2005;27(5):507-11.

11. Mars M, Plint DA, Houston WJ, Bergland O, Semb G. The Goslon Yardstick: a new system of assessing dental arch relationships in children with unilateral clefts of the lip and palate. Cleft Palate Craniofac J. 1987;24(4):314-22.

12. Atack NE, Hathorn IS, Semb G, Dowell T, Sandy JR. A New Index for Assessing Surgical Outcome in Unilateral Cleft Lip and Palate Subjects Aged Five: Reproducibility and Validity. Cleft Palate Craniofac J. 1997;34(3):242-6.

13. Chiu YT, Liao YF, Chen PKT. Initial cleft severity and maxillary growth in patients with complete unilateral cleft lip and palate. Am J Orthod Dentofacial Orthop. 2011;140(2):189-95.

14. Shaw WC, Semb G, Nelson P, Brattström V, Mølsted K, Prahl-Andersen B, et al. The Eurocleft project 1996-2000: overview. J Cranio Maxill Surg. 2001;29(3):131-40.

15. McHeik JN, Sfalli P, Bondonny JM, Levard G. Early repair for infants with cleft lip and nose. Int J Pediatr Otorhinolaryngol. 2006;70(10):1785-90.

16. Jiri B, Jana V, Michal J, Jiri K, Dana H, Miroslav T, et al. Successful early neonatal repair of cleft lip within first 8 days of life. Int J Pediatr Otorhinolaryngol. 2012;76(11):1616-26.

17. Galinier P, Salazard B, Deberail A, Vitkovitch F, Caovan C, Chausseray G, et al. Neonatal repair of cleft lip: a decision-making protocol. J Pediatr Surg. 2008;43(4):662-7.

18. Wilder RT, Flick RP, Sprung J, Katusic SK, Barbaresi WJ, Mickelson C, et al. Early exposure to anesthesia and learning disabilities in a population-based birth cohort. Anesthesiology. 2009;110(4):796-804.

19. Harris PA, Oliver NK, Slater P, Murdoch L, Moss ALH. Safety of neonatal cleft lip repair. J Plast Surg Hand Surg. 2010;44(4-5):231-6.

20. Calteux N, Schmid N, Hellers J, Kumpan S, Schmitz B. Neonatal cleft lip repair: Perioperative safety and surgical outcomes. Ann Chir Plast Esthet. 2013;58(6):638-43.

21. Shukla A, Chowdhary V. Neurodevelopmental outcome at 5 years of age after general anaesthesia or awake-regional anaesthesia in infancy (GAS): An international, multicentre, randomised, controlled equivalence trial. Acta Paediatr. 2019;108(11):2115-6.

22. Petráčková I, Zach J, Borský J, Černý M, Hacklová R, Tvrdek M, et al. Early and late operation of cleft lip and intelligence quotient and psychosocial development in 3-7 years. Early Hum Dev. 2015;91(2):149-52.

23. Mars M, Houston WJ. A preliminary study of facial growth and morphology in unoperated male unilateral cleft lip and palate subjects over 13 years of age. Cleft Palate Craniofac J. 1990;27(1):7-10.

24. Capelozza Filho L, Normando AD, da Silva Filho OG. Isolated influences of lip and palate surgery on facial growth: comparison of operated and unoperated male adults with UCLP. Cleft Palate Craniofac J. 1996;33(1):51-6.

25. Long RE, Semb G, Shaw WC. Orthodontic Treatment of the Patient with Complete Clefts of Lip, Alveolus, and Palate: Lessons of the past 60 Years. Cleft Palate-Craniofac J. 2000;37(6):1-13.

26. Bearn DR, Sandy JR, Shaw WC. Cephalometric soft tissue profile in unilateral cleft lip and palate patients. Eur J Orthod. 2002;24(3):27784.

27. Liao YF, Lin IF. Dental arch relationships after two-flap palatoplasty in Taiwanese patients with unilateral cleft lip and palate. Int J Oral Max Surg. 2009;38(11):1133-6.

28. Fudalej P, Hortis-Dzierzbicka M, Dudkiewicz Z, Semb G. Dental arch relationship in children with complete unilateral cleft lip and palate following Warsaw (one-stage repair) and Oslo protocols. Cleft Palate Craniofac J. 2009;46(6):648-53.

29. Mars M, Asher-McDade C, Brattström V, Dahl E, McWilliam J, Mølsted K, et al. A six-center international study of treatment outcome in patients with clefts of the lip and palate: Part 3. Dental arch relationships. Cleft Palate Craniofac J. 1992;29(5):405-8.

30. Mølsted K, Asher-McDade C, Brattström V, Dahl E, Mars M, McWilliam J, et al. A six-center international study of treatment outcome in patients with clefts of the lip and palate: Part 2. Craniofacial form and soft tissue profile. Cleft Palate Craniofac J. 1992;29(5):398-404. 
31. Shaw WC, Dahl E, Asher-Mcdade C, Brattström V, Mars M, Mcwilliam J, et al. A Six-Center International Study of Treatment Outcome in Patients with Clefts of the Lip and Palate: Part 5. General Discussion and Conclusions. Cleft Palate Craniofac J. 1992;29(5):413-8.

32. Mellion ZJ, Behrents RG, Johnston LE. The pattern of facial skeletal growth and its relationship to various common indexes of maturation. Am J Orthod Dentofacial Orthop. 2013;143(6):845-54.

\section{Figures}
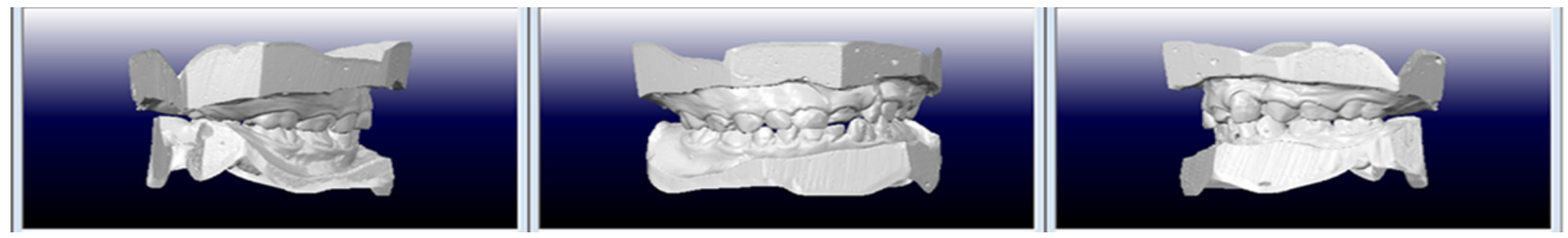

Figure 1

Scanned dental models. The 5 Year Olds' index score 1

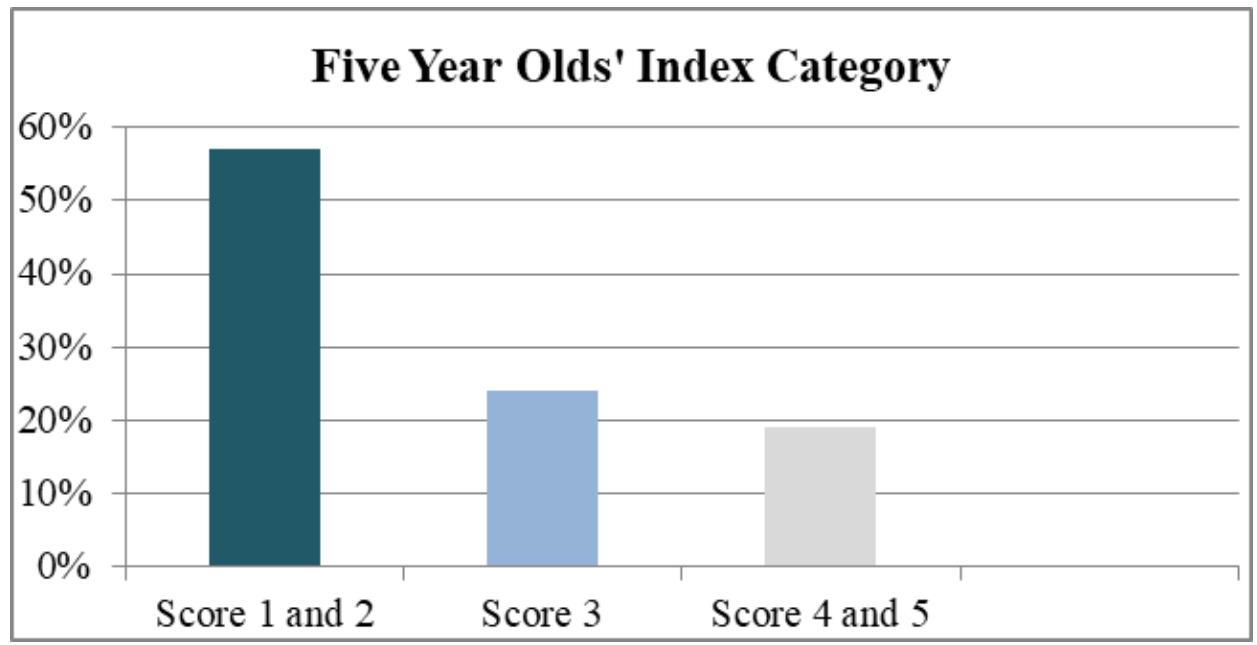

\section{Figure 2}

Graphic representation of the percentages in each 5 Year Olds' index group 


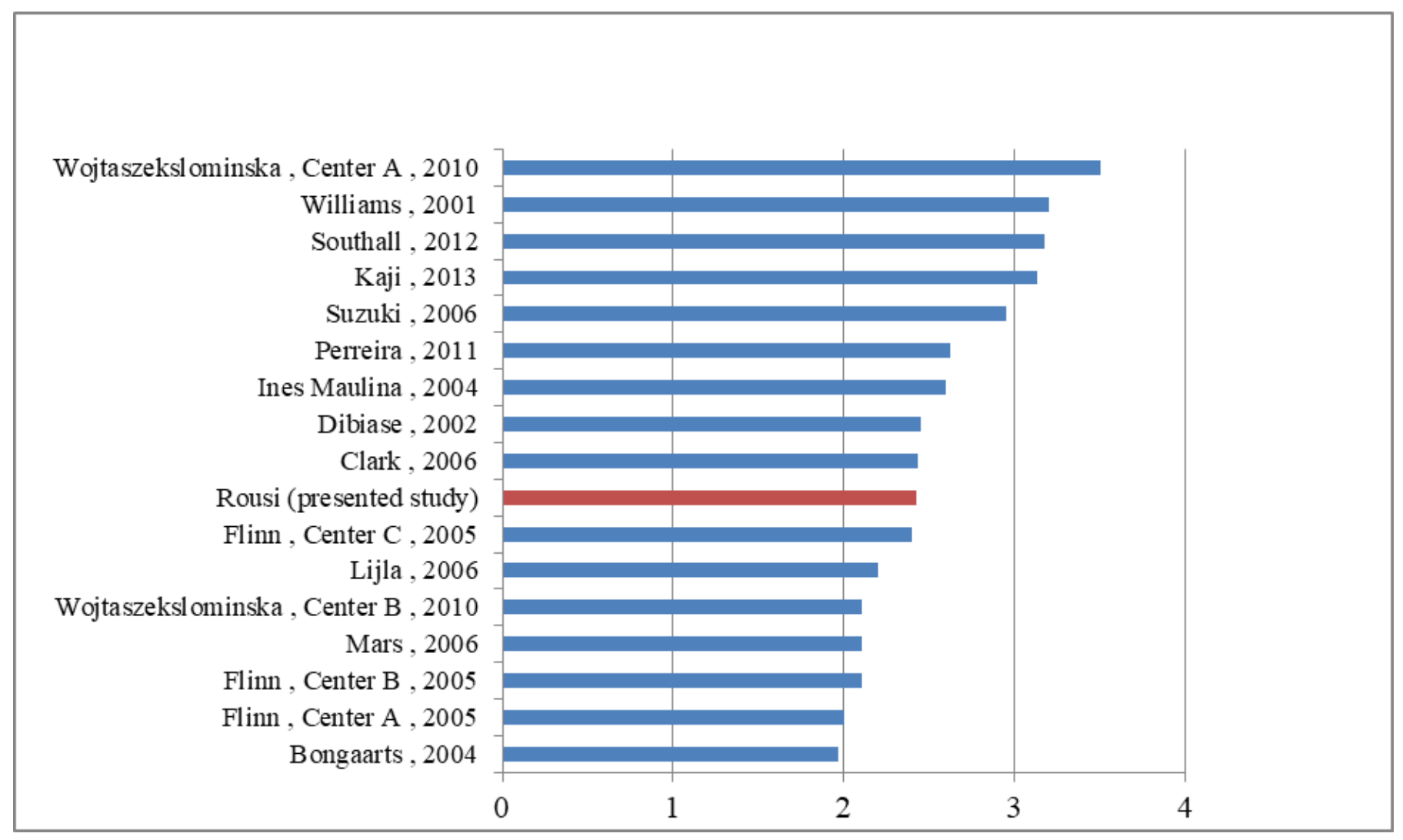

\section{Figure 3}

Comparison of 5 Year Olds' index mean score with published reports of other cleft centers 